\title{
Spesialisasi Auditor Memoderasi Kualitas Kantor Akuntan Publik, Opini Audit, Pergantian Auditor Terhadap Audit Report Lag
}

\author{
Rahman Sastrawan ${ }^{1}$ \\ Ariefanda Iqbal Perdhana ${ }^{2}$ \\ Ermina Toliang ${ }^{3}$ \\ 1,2,3Jurusan Akuntansi Politeknik Negeri Pontianak, Indonesia \\ *Correspondences : namanyarahmansastrawan@gmail.com
}

\begin{abstract}
ABSTRAK
Tujuan penelitian ini adalah untuk menganalisis pengaruh kualitas Kantor Akuntan Publik (KAP), opini audit, dan pergantian auditor terhadap audit report lag dengan spesialisasi auditor sebagai variabel moderasi. Penelitian dilaksanakan pada perusahan sektor pertanian sub sektor perkebunan yang terdaftar di Bursa Efek Indonesia periode 2017-2019. Sampel data digunakan sebanyak 13 perusahaan dengan metode purposive sampling, data dianalisis menggunakan aplikasi WarpPLS dengan pendekatan Structural Equation Modelling (SEM) berbasis Partial Least Square (PLS), sedangkan pengukuran variabel menggunakan variabel dummy. Hasil penelitian memperlihatkan bahwa kualitas KAP berpengaruh negatif, sehingga berdampak memperpendek audit report lag, sedangkan opini audit dan pergantian auditor tidak berpengaruh pada audit report lag. Spesialisasi auditor mampu memperkuat pengaruh opini audit pada audit report lag, sehingga mampu memperpendek audit report lag. Spesialisasi auditor tidak mampu memperkuat pengaruh pergantian auditor dan kualitas KAP pada audit report lag, sehingga bisa memperpanjang audit report lag.
\end{abstract}

Kata Kunci:

Kualitas KAP; Opini Audit, Pergantian Auditor; Spesialisasi Auditor; Audit Report Lag.

\section{Auditor Specialization Moderates the Quality of Public Accounting Firms, Audit Opinions, Changes in Auditors Against Audit Report Lag}

\begin{abstract}
The purpose of this study was to analyze the effect of the quality of the Public Accounting Firm (KAP), audit opinion, and auditor turnover on audit report lag with auditor specialization as a moderating variable. The research was carried out on companies in the agricultural sector of the plantation sub-sector listed on the Indonesia Stock Exchange for the 2017-2019 period. The sample data used were 13 companies with purposive sampling method, data were analyzed using the WarpPLS application with a Structural Equation Modeling (SEM) approach based on Partial Least Square (PLS), while the measurement of variables used dummy variables. The results show that the quality of KAP has a negative effect, so that it has an impact on shortening the audit report lag, while audit opinion and auditor turnover have no effect on audit report lag. Auditor specialization is able to strengthen the influence of audit opinion on audit report lag, so as to shorten audit report lag. Auditor specialization is not able to strengthen the effect of auditor turnover and KAP quality on audit report lag, so it can prolong audit report lag.
\end{abstract}

Keywords: $\quad$ KAP Quality; Audit Opinion; Auditor Change; Auditor Specialization; Audit Report Lag.

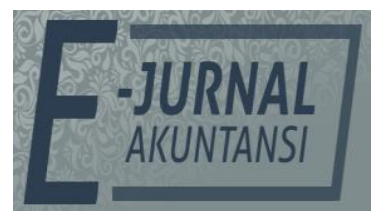

e-ISSN 2302-8556

Vol. 32 No. 1

Denpasar, Januari 2022 Hal. 265-279

DOI:

10.24843/EJA.2022.v32.i01.p20

PENGUTIPAN:

Sastrawan, R., Perdhana, A. I. \& Toliang, E. (2022). Spesialisasi Auditor

Memoderasi Kualitas Kantor Akuntan Publik, Opini Audit, Pergantian Auditor Terhadap Audit Report Lag. E-Jurnal Akuntansi, 32(1), 265-279

RIWAYAT ARTIKEL: Artikel Masuk: 21 Oktober 2021 Artikel Diterima: 12 Januari 2022

Artikel dapat diakses : https://ojs.unud.ac.id/index.php/Akuntansi/index 


\section{PENDAHULUAN}

Salah satu indikator perusahaan agar dipercaya oleh investor maupun publik adalah dengan menyajikan laporan keuangan yang telah audited. Laporan keuangan audited memberikan informasi keuangan yang akurat dan andal, sehingga pihak-pihak pemakainya bisa mengambil keputusan dengan tepat untuk kemajuan perusahaan yang mendatang maupun sekarang. Menurut Herawati (2019) laporan keuangan merupakan laporan hasil dari proses akuntansi yang digunakan sebagai informasi untuk pihak-pihak yang berkepentingan. Perusahaan-perusahaan yang terdaftar di Indonesia Stock Exchange (IDX) atau di Bursa Efek Indonesia (BEI) harus menyampaikan laporan keuangan audited. Laporan keuangan perusahaan disampaikan ke Bursa Efek Indonesia paling lambat empat bulan terakhir atau 120 hari setelah audited dari tanggal laporan keuangan tahunan, sebagaimana yang tertuang dalam Peraturan Otoritas Jasa Keuangan (POJK) Nomor 29/POJK.04/2016 tentang penyampaian laporan tahunan bagi emiten (Ikatan Akuntan Indonesia \& Hadad, 2016). Pengumuman dari Bursa Efek Indonesia menyebutkan, bahwa sebanyak 64 perusahaan yang menyampaikan laporan keuangan tahunan (Annual Report) tahun 2019 belum tepat waktu. Keterlambatan penyampaian laporan keuangan biasanya disebabkan oleh banyak faktor antara lain: kualitas Kantor Akuntan Publik (KAP) atau kualitas KAP.

Kualitas KAP ditentukan oleh auditor yang ditugaskan untuk mengaudit salah satu perusahaan. Auditor atau akuntan publik harus mematuhi kode etik profesi yang diatur oleh Ikatan Akuntan Indonesia (IAI) dan Institut Akuntan Publik Indonesia (IAPI) dengan melibatkan Pusat Pembinaan Profesi Keuangan (PPPK) dari Kementerian Keuangan. Kualitas audit menjadi lebih baik jika KAP bergabung dengan Big Four, sehingga memiliki spesialisasi auditor. Penelitian Mazkiyani \& Handoyo (2017) menyebutkan bahwa ukuran KAP berpengaruh pada audit report lag, sehingga kualitas KAP mempercepat audit laporan keuangan perusahaan. Hasil penelitian Gaol \& Sitohang (2020) juga menyebutkan bahwa ukuran KAP berpengaruh pada audit report lag. Spesialisasi auditor bagian dari kualitas audit, sebab pengetahuan dan pengalaman tentang industri merupakan salah satu instrumen dari keahlian seorang auditor, sehingga spesialisasi auditor bisa saja mempengaruhi audit report lag. Spesialisasi auditor juga dapat mempercepat keputusan dalam memberikan opini audit, sehingga pemeriksaan audit ditangani oleh ahlinya lebih cepat dalam pekerjaan audit. Opini audit dapat memberikan solusi dalam penyelesaian audit report lag. Hasil penelitian Aristika et al (2016) menyebutkan opini audit tidak berpengaruh signifikan terhadap audit report lag, sedangkan penelitian Sumartini \& Widhiyani (2014) menyebutkan opini audit mempercepat penyusunan laporan. Penelitian Sylviana (2019) menyebutkan bahwa opini audit berpengaruh pada audit report lag.

Faktor-faktor lain yang dapat mempengaruhi audit report lag adalah pergantian auditor. Pergantian auditor bisa saja menghambat penyampaian audit report lag, hal ini dapat dibuktikan pada penelitian Dewi \& Suputra, (2017) menyebutkan bahwa audit report lag dipengaruhi oleh pergantian auditor. Penelitian Telaumbanua et al (2020) menyebutkan bahwa pergantian auditor berpengaruh terhadap audit report lag. Penelitian tentang audit report lag ini merujuk pada penelitian Diastiningsih \& Tenaya (2017) dimana variabel 
dependennya adalah audit report lag, variabel moderasinya spesialisasi auditor, sedangkan variabel independennya yaitu Ukuran KAP dan audit tenure. Saran dari penelitian tersebut menambah variabel dan memperkuat objek penelitian. Permasalahan pada penelitian ini adalah apakah kualitas KAP, opini audit, pergantian auditor pada audit report lag dan apakah spesialisasi auditor memoderasi hubungan kualitas KAP, opini audit, pergantian auditor pada audit report lag.

Teori agensi (Agency Theory) merupakan teori yang menjelaskan hubungan principal dengan agent, dimana principal adalah pemegang saham yang berwenang memberikan tugas kepada agent (manajer), sedangkan manajer menjalankan tugasnya dalam memenuhi keinginan pemegang saham. Jensen dan Meckling (1987) dalam Diastiningsih \& Tenaya (2017) menyebutkan bahwa hubungan keagenan merupakan sebuah kontrak antara pemegang saham dan manajer. Hubungan antara pemegang saham dan manajer kadang terjadi konflik, yang disebabkan oleh pemegang saham ingin tujuannya tercapai yaitu menginginkan pengembalian laba yang banyak dan cepat, sedangkan manajer menginginkan insentif dan kompensasi dari kinerja yang dilakukannya. Pada praktiknya, manajer perusahaan kadang memberikan laporan informasi keuangan tidak sesuai dengan keadaan perusahaan yang sebenarnya, hal ini disebabkan manajer perusahaan mengetahui keadaan perusahaan, sehingga terjadi manajemen laba. Ketidaksesuaian informasi bisa dikatakan asimetri informasi, untuk menghindari terjadinya asimetri informasi, perusahaan harus tepat waktu dalam penyampaian pelaporan keuangan (Lisa, 2012). Teori agensi pada penelitian ini untuk melihat hubungan pemegang saham dan manajer perusahaan dalam ketepatan waktu dalam penyampaian laporan keuangan. Dengan demikian, pihak pemegang saham memilih kualitas KAP, kualitas KAP yang baik dilihat dari bergabungnya perusahaan ke KAP big four atau tidak, sehingga memberikan opini yang sesuai dengan keadaan sebenarnya, selain itu pergantian dan spesialisasi auditor juga memberikan kontribusi dalam pemeriksaan audit. Hubungan pemegang saham dan manajer dalam teori agensi juga dapat mempengaruhi audit report lag.

Teori kepatuhan (Compliance Theory) merupakan sikap untuk taat dan tunduk terhadap kebijakan, peraturan, dan ketentuan dalam setiap aktivitas kegiatan, begitu pula dalam penyampaian pelaporan keuangan harus taat dan tunduk terhadap kepatuhan sesuai Peraturan Otoritas Jasa Keuangan (POJK) Nomor 29/POJK. 04/ 2016. Susilowati (2004) dalam Darsono (2015) menyebutkan ada dua perspektif pada literatur sosiologi yang berkaitan dengan kepatuhan hukum yaitu instrumental dan normatif. Perspektif instrumental beranggapan bahwa individu secara umum didorong oleh keinginan pribadi tentang perubahan perilaku, sedangkan perspektif normatif berhubungan dengan moral. Seseorang yang patuh berarti konsisten dengan norma-norma yang berlaku, sehingga komitmen normatif melalui moralitas mematuhi hukum adalah kewajiban personal, sedangkan komitmen normatif melalui legitimasi adalah patuh terhadap peraturan yang telah dibuat otoritas penyusun hukum yang memiliki hak untuk mendikte perilaku. Teori kepatuhan mempunyai hubungan dengan audit report lag, dimana perusahaan dituntut untuk patuh dalam penyampaian laporan keuangan. 
Laporan keuangan bertujuan untuk memberikan gambaran informasi pada laporan laba rugi dan komprehensif lainya, perubahan modal, posisi keuangan, arus kas, serta catatan atas laporan keuangan. Peraturan Otoritas Jasa Keuangan (POJK) Nomor 29/POJK. 04/ 2016, dimana OJK mengharuskan perusahaan yang go public menyampaikan laporan keuangannya paling lambat bulan keempat setelah tahun buku.

Audit adalah suatu proses evaluasi bukti secara objektif tentang kegiatan yang dilakukan dengan tujuan melihat kesesuaian laporan keuangan dengan prinsip akuntansi atau aturan yang berlaku (Mulyadi, 2014). Audit menurut Agoes (2017) adalah suatu pemeriksaan terhadap laporan keuangan secara kritis dan sistematis oleh pihak independen. Audit yang dilakukan oleh auditor bisa berdampak pada audit report lag, sehingga pemeriksaan laporan keuangan bisa tepat waktu.

Kantor akuntan publik (KAP) yang besar bisa dikatakan berkualitas jika, mempunyai auditor yang ahli dan kompeten dalam mendeteksi adanya kelalaian pada suatu proses audit. KAP yang besar yang terkenal di Indonesia adalah KAP big four, sebab para auditornya kompeten, professional, serta mempunyai skill yang andal. KAP big four yang terkenal di Indonesia terdiri dari: KAP (PWC) Price Waterhouse Coopers, bekerjasama dengan KAP Drs. H Sutanto \& Rekan, Haryanto S \& Rekan. KAP (Deloitte) Deloitte Touche Thomatsu, bekerjasama dengan KAP, Osman \& Rekan. KAP (KPMG) Klynveld Peat Marwick Goerdeler, bekerjasama dengan KAP Sidharta-Sidharta \& Widjaja. KAP (E\&Y) Ernest \& Young, bekerjasama dengan KAP Purwantono, Sungkoro, \& Surja. Kualitas KAP ditentukan juga dari kualitas audit yang dilakukan oleh auditor, sehingga audit report lag terhadap laporan keuangan bisa disampaikan tepat waktu. Kualitas KAP yang baik dilihat dari besar kecilnya ukuran KAP yang dimiliki oleh seorang akuntan. Penelitian Diastiningsih \& Tenaya (2017) menyebutkan bahwa ukuran KAP berpengaruh negatif terhadap audit report lag. Penelitian Nur Affifah \& Susilowati (2021) menyebutkan bahwa ukuran KAP berpengaruh terhadap audit report lag. Penelitian Ariani \& Bawono (2018) menyebutkan bahwa ukuran KAP berpengaruh negatif terhadap audir report lag. Dengan demikian, dapat dikemukakan hipotesis pertama adalah.

$\mathrm{H}_{1}$ : Kualitas KAP berpengaruh negatif terhadap audit report lag.

Opini audit adalah pernyataan pendapat auditor dari proses audit yang telah dilakukan Arens et al (2017). Pernyataan pendapat auditor dikemukakan setelah pemeriksaan atas bukti-bukti audit, sehingga dapat disimpulkan apakah memberikan opini atau tidak. Opini audit terbagi menjadi dua yaitu: opini tanpa modifikasi (unmodified opinion) dan opini dengan modifikasian (modified opinion). Opini dengan modifikasi dalam SA 705 terdiri dari: Opini wajar dengan pengecualian (Qualified Opinion). Opini tidak wajar (Adverse Opinion), opini tidak menyampaikan pendapat (disclaimer opinion) (Agoes, 2017). Perusahaanperusahaan yang listing di Bursa Efek Indonesia (BEI) harus menyampaikan laporan keuangan tahunan audited, paling lama empat bulan setelah tahun buku, sehingga opini yang diberikan oleh auditor kepada klien dapat mempengaruhi audit report lag. Hasil penelitian Sumartini \& Widhiyani (2014) menyebutkan bahwa opini audit berpengaruh terhadap audit report lag, sehingga opini yang diberikan auditor akan berdampak pada audit report lag. Penelitian Dewangga \& 
Laksito (2015) dan Togasima \& Christiawan (2014) menyatakan bahwa opini audit berpengaruh pada audit report lag.

$\mathrm{H}_{2}$ : Opini audit berpengaruh positif terhadap audit report lag.

Ketepatan waktu dalam penyampaian laporan keuangan ke Otoritas Jasa Keuangan (OJK) tergantung pada auditornya. Auditor yang sering mengaudit lebih cenderung tepat waktu penyampaian laporan dibandingkan dengan auditor yang baru, sebab pergantian auditor yang baru butuh waktu lama dalam mengidentifikasi entitas bisnis tersebut, sehingga menghambat melakukan audit report lag. Penelitian Tambunan (2014) menyebutkan bahwa pergantian auditor berpengaruh pada audit report lag.

Pergantian auditor adalah pergantian jasa audit yang dilakukan oleh perusahaan terhadap KAP maupun auditor. Peraturan Otoritas Jasa Keuangan (POJK) Nomor 13/POJK. 03/2017 tentang Jasa Akuntan Publik dan Kantor Akuntan Publik, menyebutkan bahwa pelaksanaan kegiatan jasa keuangan dibatasi paling lama tiga periode berturut-turut atau tiga tahun buku pada perusahaan serupa. Hasil penelitian Ratnaningsih \& Dwirandra (2016) dan Praptika \& Rasmini (2016) menyatakan bahwa pergantian auditor berpengaruh terhadap audit report lag. Dengan demikian, dapat dikemukakan hipotesis ketiga adalah sebagai berikut.

$\mathrm{H}_{3}$ : Pergantian auditor berpengaruh positif terhadap audit report lag.

Spesialisasi auditor merupakan keahlian seseorang dalam melakukan pekerjaan audit. Spesialisasi auditor ditentukan oleh lamanya bekerja di KAP, memiliki sertifikat kompetensi, dan sering melakukan pemeriksaan audit pada klien atau industri serupa tiap tahunnya. Mayhew \& Wilkins (2003) berpendapat bahwa auditor yang merupakan spesialis pada suatu industri memiliki keahlian untuk menyebarkan (spread) biaya pelatihan yang berkaitan dengan suatu industri secara spesifik kepada lebih banyak klien, kemudian menghasilkan ekonomi yang baik dan tidak dapat dengan mudah dilakukan oleh auditor yang bukan merupakan spesialis industri. Hasil penelitian Adiwibowo \& Makhabati (2019) dan Yudhi et al (2020) menyatakan spesialisasi auditor berpengaruh terhadap audit report lag, sehingga memiliki peran sebagai pemoderasi pada kualitas KAP.

Kantor Akuntan Publik (KAP) yang berafiliasi dengan big four memiliki kualitas audit lebih baik dari KAP lain. Spesialisasi auditor biasanya dimiliki oleh KAP big four, sebab kualitas audit yang dihasilkan lebih baik. Menurut Panjaitan dalam Nurintiati \& Purwanto (2017) menyebutkan bahwa perusahaan yang diaudit oleh spesialisasi auditor lebih baik daripada tidak diaudit oleh spesialisasi auditor.

$\mathrm{H}_{4}$ : Spesialisasi auditor memperkuat pengaruh negatif kualitas KAP terhadap audit report lag.

Opini audit diberikan perusahaan atas dasar pemeriksaan laporan keuangan oleh auditor yang berkompeten atau disebut spesialisasi auditor. Spesialisasi auditor mempunyai kemampuan dalam menyatakan pendapat terhadap laporan keuangan, sehingga dapat mempengaruhi audit Report lag. Opini audit yang dilakukan oleh auditor akan mempersingkat laporan audit (Sumartini \& Widhiyani, 2014). Hasil penelitian Azzuhri et al (2019) menyatakan bahwa opini audit berpengaruh terhadap audit report lag dengan variabel moderasinya spesialisasi auditor. Penelitian Utami et al (2018) dan Hapsari et al 
(2016) menyatakan bahwa opini audit berpengaruh pada audit report lag, sehingga orang yang memiliki kemampuan spesialisasi auditor dapat mempersingkat proses audit laporan keuangan perusahaan. Dengan demikian, dapat dikemukakan hipotesis kelima adalah sebagai berikut.

$\mathrm{H}_{5}$ : Spesialisasi auditor memperkuat pengaruh positif opini audit terhadap audit report lag.

Pergantian auditor sering dilakukan oleh perusahaan, sebab mencari auditor yang andal dalam pemeriksaan laporan keuangan, selain itu pergantian auditor juga ditetapkan oleh POJK. Hasil penelitian Dewi \& Suputra (2017) menyebutkan bahwa spesialisasi auditor tidak mampu memperlemah pengaruh pergantian auditor terhadap audit report lag. Penelitian Ratnaningsih \& Dwirandra (2016) menyatakan bahwa spesialisasi auditor memoderasi pergantian auditor pada audit report lag. Hasil penelitian Ginting (2019) menyatakan pergantian auditor berpengaruh positif terhadap audit report lag, sehingga spesialisasi seorang auditor dapat memperkuat pengaruh audit report lag. Dengan demikian, dapat dikemukakan hipotesis keenam adalah sebagai berikut.

$\mathrm{H}_{6}$ : Spesialisasi auditor memperkuat pengaruh positif pergantian auditor terhadap audit report lag.

Berdasarkan uraian latar belakang, tinjauan pustaka dan hipotesis, dibuatlah kerangka konseptual yang disajikan pada Gambar 1.

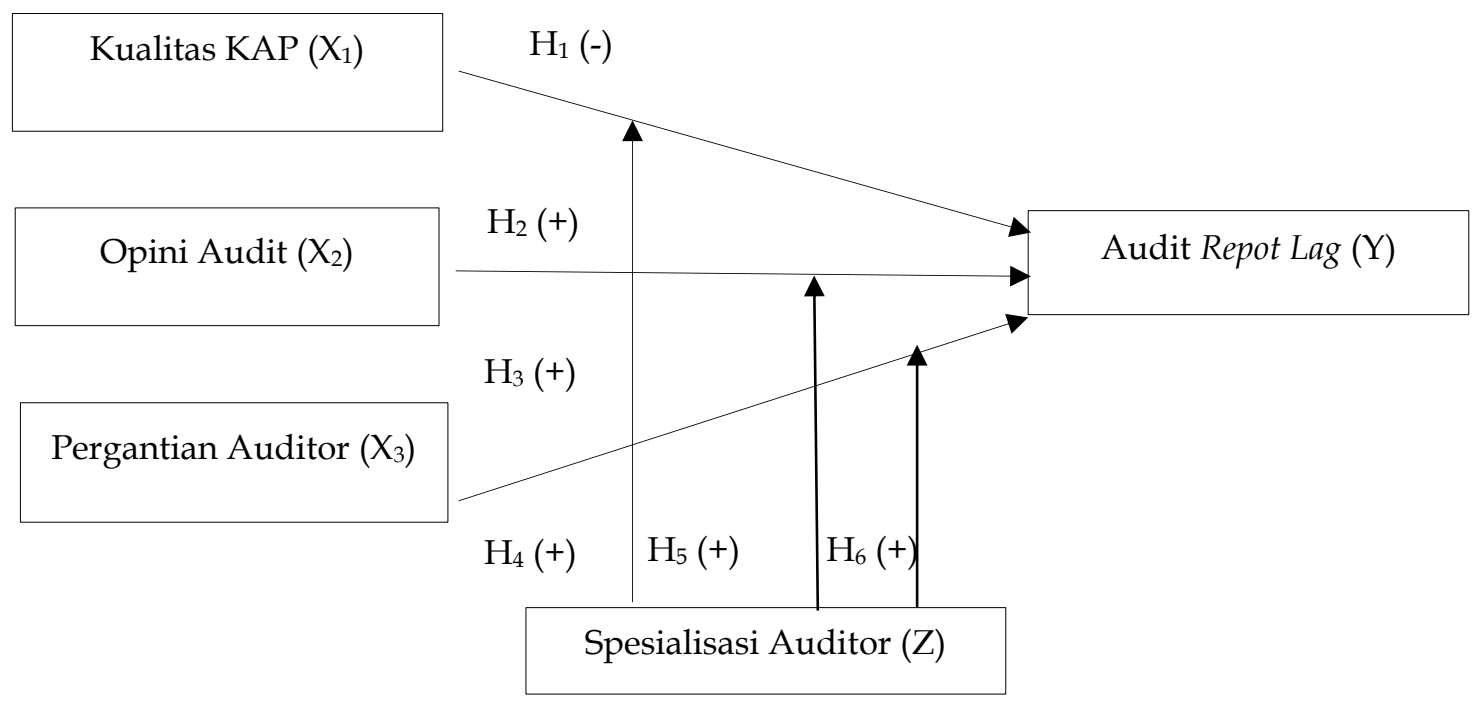

Sumber: Data Penelitian, 2021

\section{Gambar 1. Kerangka Penelitian}

\section{METODE PENELITIAN}

Penelitian ini merupakan kuantitatif asosiatif, yaitu menjelaskan hubungan antara variabel satu dengan variabel lainya. Kualitas $\operatorname{KAP}\left(X_{1}\right)$, opini audit $\left(X_{2}\right)$, pergantian auditor $\left(X_{3}\right)$ sebagai variabel independen (laten eksogen), spesialisasi auditor $(\mathrm{Z})$ sebagai variabel moderasi, dan audit report lag $(\mathrm{Y})$ sebagai variabel dependen (laten endogen). Pengujian hipotesis pada penelitian ini menggunakan aplikasi WarpPLS dengan pendekatan Structural Equation Modelling (SEM) berbasis Partial Least Square (PLS). Kock dan Latan dalam Ghozali (2015) 
menyebutkan WarpPLS merupakan perangkat lunak untuk mengidentifikasi suatu hubungan non linier di antara variabel laten dan mengoreksi nilai koefisien jalur yang lebih sesuai. Tempat penelitian dilakukan pada perusahaan sektor pertanian sub sektor perkebunan yang listing di Bursa Efek Indonesia (BEI). Data sekunder yang digunakan dalam penelitian berbentuk time series, yaitu laporan keuangan audited perusahaan pada sub sektor perkebunan 3 tahun berturut-turut. Populasi pada penelitian ini adalah perusahaan di sektor pertanian sub sektor perkebunan berjumlah 13 dari 19 perusahaan yang ada di BEI. Sampel dalam penelitian ini adalah laporan keuangan perusahaan pertanian sub sektor perkebunan periode tahun 2017-2019, memiliki tahun buku 31 Desember dan perusahaan yang menerbitkan laporan tidak melebihi empat bulan.

Pengukuran variabel kualitas KAP dalam penelitian ini menggunakan variabel dummy. Perusahaan yang diaudit oleh KAP big four diberi angka 1, sedangkan sebaliknya perusahaan diaudit non-KAP big four diberi angka 0 . Pengukuran variabel opini audit menggunakan variabel dummy. Perusahaan mendapat opini tanpa modifikasi (unmodified opinion) diberi angka 1, sedangkan perusahaan mendapat opini dengan modifikasian (modified opinion) diberi angka 0 .

\section{METODE PENELITIAN}

Penelitian ini merupakan kuantitatif asosiatif, yaitu menjelaskan hubungan antara variabel satu dengan variabel lainya. Kualitas $\operatorname{KAP}\left(X_{1}\right)$, opini audit $\left(X_{2}\right)$, pergantian auditor $\left(X_{3}\right)$ sebagai variabel independen (laten eksogen), spesialisasi auditor $(\mathrm{Z})$ sebagai variabel moderasi, dan audit report lag $(\mathrm{Y})$ sebagai variabel dependen (laten endogen). Pengujian hipotesis pada penelitian ini menggunakan aplikasi WarpPLS dengan pendekatan Structural Equation Modelling (SEM) berbasis Partial Least Square (PLS). Kock dan Latan dalam Ghozali (2015) menyebutkan WarpPLS merupakan perangkat lunak untuk mengidentifikasi suatu hubungan non linier di antara variabel laten dan mengoreksi nilai koefisien jalur yang lebih sesuai. Tempat penelitian dilakukan pada perusahaan sektor pertanian sub sektor perkebunan yang listing di Bursa Efek Indonesia (BEI). Data sekunder yang digunakan dalam penelitian berbentuk time series, yaitu laporan keuangan audited perusahaan pada sub sektor perkebunan 3 tahun berturut-turut. Populasi pada penelitian ini adalah perusahaan di sektor pertanian sub sektor perkebunan berjumlah 13 dari 19 perusahaan yang ada di BEI. Sampel dalam penelitian ini adalah laporan keuangan perusahaan pertanian sub sektor perkebunan periode tahun 2017-2019, memiliki tahun buku 31 Desember dan perusahaan yang menerbitkan laporan tidak melebihi empat bulan.

Pengukuran variabel kualitas KAP dalam penelitian ini menggunakan variabel dummy. Perusahaan yang diaudit oleh KAP big four diberi angka 1, sedangkan sebaliknya perusahaan diaudit non-KAP big four diberi angka 0 . Pengukuran variabel opini audit menggunakan variabel dummy. Perusahaan mendapat opini tanpa modifikasi (unmodified opinion) diberi angka 1, sedangkan perusahaan mendapat opini dengan modifikasian (modified opinion) diberi angka 0 .

Pengukuran variabel pergantian auditor dalam penelitian ini menggunakan variabel dummy. Perusahaan melakukan pergantian auditor diberi 
angka 1, sedangkan perusahaan tidak mengganti auditor diberi angka 0 . Pengukuran variabel spesialisasi auditor dalam penelitian ini menggunakan variabel dummy. Untuk menentukan spesialis atau tidak dengan memperhitungkan jumlah perusahaan diaudit oleh KAP yang serupa pada sub sektor industri dibagi dengan jumlah perusahaan sub sektor industri dikali $100 \%$ (Dewi \& Suputra, 2017). Apabila perhitungan proporsi lebih dari atau sama dengan $10 \%$, maka perusahaan yang diaudit oleh spesialisasi auditor yang sama diberi angka 1, sedangkan perhitungan kurang dari 10\% perusahaan tidak diaudit oleh spesialisasi auditor diberi angka 0. Pengukuran variabel audit report lag dengan melihat rentang hari antara tanggal laporan keuangan dibukukan perusahaan sampai dengan laporan keuangan audited diterbitkan atau ditandatangani oleh auditor, yaitu dengan menghitung jumlah hari dari tanggal 31 Desember sampai laporan keuangan audited.

Penelitian ini menggunakan alat analisis yaitu WarpPLS versi 7.0, WarpPLS adalah sebuah pendekatan persamaan struktural yang kuat (SEM) perangkat lunak untuk mengidentifikasi hubungan non linier di antara variabel laten dan mengoreksi nilai koefisien jalur yang sesuai Ghozali \& Latan (2015). Analisis pada WarpPLS ini dilaksanakan dengan dua tahapan, yaitu pengujian kelayakan model (outer model dan inner model) dan pengujian hipotesis.

Outer model merupakan pengujian untuk mengukur validitas dan reliabilitas suatu data, dengan melihat validitas konvergen (convergent validity), validitas diskriminan (discriminant validity) serta reliabilitas. Ghozali \& Latan (2015), menyatakan bahwa inner model bertujuan untuk memprediksi hubungan antar variabel laten. Pengujian inner model dapat dilihat dari nilai R-Square dan QSquare. Nilai R-Square berada pada angka 0,70 model kuat, 0,45 sedang dan 0,25 lemah.

Uji hipotesis dilakukan untuk menjelaskan arah hubungan antara variabel independen dan variabel dependennya. Pengujian dilakukan dengan melihat diagram path (path diagram) atau diagram jalur atas model yang telah dibuat. Program WarpPLS 7.0 dapat secara bersamaan melakukan pengujian model struktural yang komplek, sehingga dapat dibentuk persamaan struktural hipotesis sebagai berikut.

$Y=\beta_{1} X_{1}+\beta_{2} X_{2}+\beta_{3} X_{3}+\beta_{4} Z X_{1}+\beta_{5} Z X_{2}+\beta_{6} Z X_{3}+\varepsilon$

Keterangan :

$\begin{array}{ll}\mathrm{Y} & =\text { Audit Report Lag } \\ \beta_{1}, \beta_{2}, \beta_{3}, \beta_{4}, \beta_{5} & =\text { Koefisien Jalur } \\ \mathrm{X}_{1} & =\text { Kualitas KAP } \\ \mathrm{X}_{2} & =\text { Opini Audit } \\ \mathrm{X}_{3} & =\text { Pergantian Auditor } \\ \mathrm{Z} & =\text { Spesialisasi Auditor } \\ \varepsilon & =\text { Nilai Residu }\end{array}$

\section{HASIL DAN PEMBAHASAN}

Penelitian ini dilakukan pada perusahaan sektor pertanian sub sektor perkebunan yang listing di Bursa Efek Indonesia (BEI) periode 2017-2019. Pada Tabel 1 disajikan data penelitian yang digunakan untuk penelitian. 
Tabel 1. Sampel Penelitian

\begin{tabular}{llc}
\hline No & \multicolumn{1}{c}{ Kriteria } & Total Perusahaan \\
\hline $1 \quad \begin{array}{l}\text { Perusahaan sektor pertanian sub sektor perkebunan } \\
\text { terdaftar di BEI periode 2017-2019 }\end{array}$ & 19 \\
$2 \quad \begin{array}{l}\text { Perusahaan tidak lengkap mempublikasikan laporan } \\
\text { tahunan periode 2017-2019 }\end{array}$ & $(5)$ \\
$\quad \begin{array}{l}\text { Perusahaan tidak mempublikasikan laporan tahunan } \\
\text { periode 2017-2019 }\end{array}$ & 13 \\
Sampel akhir & 13 \\
Tahun pengamatan & 3 \\
Total sampel penelitian : (13 Perusahaan x 3 Tahun) & 39 \\
\hline
\end{tabular}

Sumber: Data Penelitian, 2021

Tabel 1. Menyajikan data penelitian yang diperoleh dari laporan tahunan perusahaan di sektor pertanian sub sektor perkebunan yang terdaftar di Bursa Efek Indonesia (BEI) periode 2017-2019. Jumlah perusahaan sub sektor perkebunan yang terdaftar di BEI sebanyak 19 perusahaan, kemudian data digunakan hanya 13 perusahaan. Data yang telah diperoleh diolah sesuai dengan kriteria yang telah ditetapkan.

Tabel 2. Hasil Uji Validitas Konvergen

\begin{tabular}{ccc}
\hline Variabel Penelitian & Factor Loading & Keterangan \\
\hline Kualitas KAP $(\mathrm{X} 1)$ & 1,000 & Valid \\
Opini Audit $(\mathrm{X} 2)$ & 1,000 & Valid \\
Pergantian Auditor $(\mathrm{X} 3)$ & 1,000 & Valid \\
Spesialisasi Auditor $(\mathrm{Z})$ & 1,000 & Valid \\
Audit Report Lag $(\mathrm{Y})$ & 1,000 & Valid \\
\hline
\end{tabular}

Sumber: Data Penelitian, 2021

Uji validitas konvergen dilakukan untuk mengukur besarnya korelasi variabel laten dengan indikator lainnya. Validitas konvergen ditentukan dengan melihat nilai factor loading, jika nilai factor loading $>0,05$, maka memenuhi kriteria validitas konvergen, sedangkan jika nilai factor loading $<0,05$, maka tidak memenuhi kriteria validitas konvergen. Hasil uji validitas konvergen pada Tabel 2 memperlihatkan bahwa nilai factor loading pada tiap-tiap variabel $>0,05$, sehingga dapat memenuhi kriteria validitas konvergen atau valid.

\section{Tabel 3. Hasil Uji Validitas Diskriminan AVE}

\begin{tabular}{|c|c|c|c|c|c|}
\hline $\begin{array}{l}\text { Variabel } \\
\text { Penelitian }\end{array}$ & $\begin{array}{l}\text { Kualitas } \\
\text { KAP }\end{array}$ & $\begin{array}{l}\text { Opini } \\
\text { Audit }\end{array}$ & $\begin{array}{c}\text { Pergantian } \\
\text { Auditor }\end{array}$ & $\begin{array}{c}\text { Spesialisasi } \\
\text { Auditor }\end{array}$ & $\begin{array}{c}\text { Audit Report } \\
\text { Lag }\end{array}$ \\
\hline Kualitas KAP & 1,000 & 0,240 & $-0,024$ & 0,232 & $-0,398$ \\
\hline Opini Audit & 0,240 & 1,000 & 0,047 & 0,220 & $-0,276$ \\
\hline $\begin{array}{l}\text { Pergantian } \\
\text { Auditor }\end{array}$ & $-0,024$ & 0,047 & 1,000 & 0,024 & 0,183 \\
\hline $\begin{array}{l}\text { Spesialisasi } \\
\text { Auditor }\end{array}$ & $-0,398$ & $-0,276$ & 0,183 & $-0,158$ & 1,000 \\
\hline $\begin{array}{l}\text { Audit Report } \\
\text { Lag }\end{array}$ & 0,232 & 0,220 & 0,024 & 1,000 & $-0,158$ \\
\hline
\end{tabular}

Sumber: Data Penelitian, 2021

Uji validitas diskriminan dilakukan untuk mengukur berapa besar korelasi antara variabel laten. Kriteria validitas diskriminan terpenuhi atau valid apabila 
nilai akar average variance extracted (AVE) lebih besar daripada koefisien antara variabel-variabel laten. Hasil uji validitas yang disajikan pada Tabel 3 memperlihatkan bahwa nilai akar AVE pada satu variabel laten sebesar 1.000 lebih besar dari variabel laten lainya, sehingga tiap-tiap variabel laten memenuhi kriteria validitas diskriminan.

Tabel 4. Hasil Uji Reliabilitas

\begin{tabular}{ccc}
\hline Variabel Laten & Cronbach's Alpha & Keterangan \\
\hline Kualitas KAP & 1,000 & Reliabel \\
Opini Audit & 1,000 & Reliabel \\
Pergantian Auditor & 1,000 & Reliabel \\
Spesialisasi Auditor & 1,000 & Reliabel \\
Audit Report Lag & 1,000 & Reliabel \\
\hline
\end{tabular}

Sumber: Data Penelitian, 2021

Uji reliabilitas dilakukan untuk mengukur nilai Cronbach's Alpha dengan mencocokan model pada tiap-tiap variabel. Suatu model dikatakan reliabel jika nilai Cronbach's Alpha $>0,7$. Hasil output uji reliabilitas pada Tabel 4 memperlihatkan bahwa nilai cronbach' Alpha lebih besar 0,7, sehingga tiap-tiap variabel reliabel.

Tabel 5. Hasil Uji R-Square \& Q-Square

\begin{tabular}{ccc}
\hline Variabel Laten Endogen & R-Square & Q-Square \\
\hline Audit Report Lag $(\mathrm{Y})$ & 0,356 & 0,387
\end{tabular}

Sumber: Data Penelitian, 2021

Pengujian inner model dilakukan untuk mengetahui berapa besar ukuran kelayakan dan kebaikan antara konstruk variabel eksogen dan endogen, sehingga dapat menginterpretasikan hasil uji hipotesis. Uji inner model dilakukan dengan melihat nilai R-Square (koefisien determinasi), Q-Square (relevansi prediksi) dan Goodnes of Fit (Gof).

Hasil uji koefisien determinasi pada Tabel 5, memperlihatkan bahwa nilai R-Square sebesar 0, 356 atau 35,6\%, sehingga dapat dijelaskan pengaruh variabel kualitas $\operatorname{KAP}\left(\mathrm{X}_{1}\right)$, opini audit $\left(\mathrm{X}_{2}\right)$, dan pergantian audit $\left(\mathrm{X}_{3}\right)$ terhadap audit report lag $(\mathrm{Y})$ sebesar 35,6\% serta mempunyai hubungan yang lemah, sedangkan $64,4 \%$ dijelaskan variabel lain diluar model. Uji relevansi prediksi (Q-Square) dilakukan untuk mengetahui seberapa baik pengamatan oleh model. Relevansi prediksi dikatakan baik jika nilai pengamatan $Q$-Square $>0,05$, sedangkan nilai pengamatan $Q$-Square $<0,05$ artinya model penelitian tidak relevan. Hasil uji relevansi prediksi pada Tabel 5, memperlihatkan bahwa nilai $Q$-Square $>0,05$. Hal ini menunjukan bahwa variabel laten endogen audit report lag dapat dikatakan relevan (baik).

Tabel 6. Uji Goodness of Fit

\begin{tabular}{|c|c|c|c|c|}
\hline No & Model & Kriteria Fit & Hasil Ril & Keterangan \\
\hline 1 & $\begin{array}{c}\text { Average Path } \\
\text { Coefficient (AVC) }\end{array}$ & $\mathrm{P}<0,05$ & $0,183, P=0,056$ & Baik \\
\hline 2 & $\begin{array}{c}\text { Average block VIF } \\
\text { (AVIF) }\end{array}$ & $\begin{array}{l}\text { Diterima jika } \\
<5\end{array}$ & 2,677 & Diterima \\
\hline
\end{tabular}

Sumber: Data Penelitian, 2021

Pengujian Goodnes of Fit dilakukan untuk menginterpretasikan hasil uji hipotesis apakah layak atau baik dengan cara melihat nilai model fit dan quality 
indices. Hasil uji goodness of fit pada Tabel 6, memperlihatkan bahwa nilai riil model average path coefficient (AVC) sebesar 0,183 dengan tingkat signifikansi $\mathrm{P}=0,056$. Hal ini menunjukan bahwa koefisien pada setiap jalur mempunyai pengaruh signifikan dari variabel eksogen terhadap variabel endogen serta variabel moderasi ke variabel endogen. Nilai riil model average block VIF (AVIF) sebesar $2,677<0,05$ dapat diterima. Hal ini menunjukan bahwa indikator kedua variabel tidak terjadi multikolinearitas, dengan kata lain tidak ada korelasi kedua variabel.

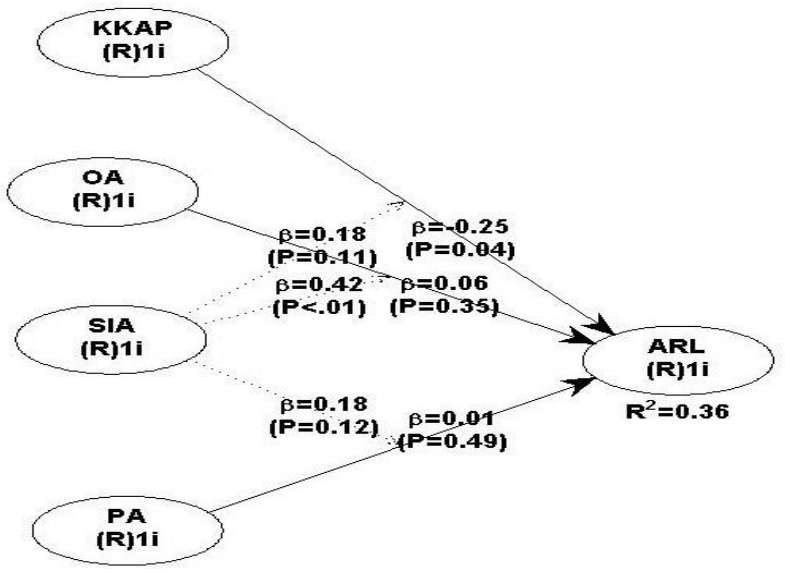

\section{Gambar 2. Diagram Jalur}

Sumber: Data Penelitian, 2021

Gambar 2. diagram jalur memperlihatkan nilai signifikansi hipotesis yang diolah menggunakan WarpPLS versi 7.0, sehingga dapat dibentuk persamaan struktural sebagai berikut:

$\mathrm{Y}=-0,25 \mathrm{X}_{1}+0,06 \mathrm{X}_{2}+0,01 \mathrm{X}_{3}+0,18 \mathrm{ZX} \mathrm{X}_{1}+0,42 \mathrm{Z} \mathrm{X}_{2}+0,18 \mathrm{Z} \mathrm{X}_{3}+\varepsilon$

\section{Tabel 7. Hasil Uji Hipotesis}

\begin{tabular}{cccccc}
\hline Hipotesis & \multicolumn{2}{c}{ Hubungan Antara Variabel } & $\begin{array}{c}\text { Koefisien } \\
\text { Jalur }\end{array}$ & P-Value & Keterangan \\
\hline $\mathrm{H}_{1}$ & $\begin{array}{c}\text { Kualitas KAP } \\
\left(\mathrm{X}_{1}\right)\end{array}$ & $\begin{array}{c}\text { Audit Report } \\
\text { Lag }(\mathrm{Y})\end{array}$ & $-0,251$ & 0,044 & Diterima \\
& $\begin{array}{c}\text { Opini Audit } \\
\left(\mathrm{X}_{2}\right)\end{array}$ & $\begin{array}{c}\text { Audit Report } \\
\text { Lag }(\mathrm{Y})\end{array}$ & 0,062 & 0,347 & Ditolak \\
$\mathrm{H}_{2}$ & $\begin{array}{c}\text { Pergantian } \\
\text { Auditor }\left(\mathrm{X}_{3}\right)\end{array}$ & $\begin{array}{c}\text { Audit Report } \\
\text { Lag }(\mathrm{Y})\end{array}$ & 0,005 & 0,488 & Ditolak \\
$\mathrm{H}_{3}$ & $\begin{array}{c}\text { Interaksi } \\
(\mathrm{Z} \mathrm{X})\end{array}$ & $\begin{array}{c}\text { Audit Report } \\
\text { Lag }(\mathrm{Y})\end{array}$ & 0,179 & 0,118 & Ditolak \\
$\mathrm{H}_{4}$ & $\begin{array}{c}\text { Interaksi } \\
\left(\mathrm{Z} \mathrm{X} \mathrm{X}_{2}\right)\end{array}$ & $\begin{array}{c}\text { Audit Report } \\
\text { Lag }(\mathrm{Y})\end{array}$ & 0,423 & 0,001 & Diterima \\
$\mathrm{H}_{5}$ & $\begin{array}{c}\text { Interaksi } \\
\left(\mathrm{Z} \mathrm{X} \mathrm{X}_{3}\right)\end{array}$ & $\begin{array}{c}\text { Audit Report } \\
\text { Lag }(\mathrm{Y})\end{array}$ & 0,181 & 0,115 & Ditolak \\
$\mathrm{H}_{6}$ & & & & & \\
\hline
\end{tabular}

Sumber: Data Penelitian, 2021 
Hasil uji hipotesis pada Tabel 7, memperlihatkan bahwa nilai koefisien jalur kualitas KAP sebesar -0,251, hal ini memberikan penjelasan bahwa apabila kualitas KAP mendapatkan kenaikan satu satuan, akan memberikan penurunan pada audit report lag sebesar 0,251 satuan dengan anggapan variabel lainnya sama dengan nol. Nilai koefisien jalur opini audit sebesar 0,062, hal ini memberikan penjelasan bahwa apabila opini audit mendapatkan kenaikan satu satuan, akan memberikan peningkatan pada audit report lag sebesar 0,062 satuan dengan anggapan variabel lainnya sama dengan nol.

Nilai koefisien jalur pergantian auditor sebesar 0,005, hal ini memberikan penjelasan bahwa apabila pergantian auditor mendapatkan kenaikan satu satuan, dapat memberikan peningkatan pada audit report lag sebesar 0,005 satuan dengan anggapan variabel lainnya sama dengan nol. Nilai koefisien jalur interaksi antara kualitas KAP dengan spesialisasi auditor sebesar 0,179, hal ini memberikan penjelasan bahwa apabila interaksi antara kualitas KAP dan spesialisasi auditor mendapat kenaikan satu satuan, dapat memberikan peningkatan audit report lag sebesar 0,179 satuan.

Nilai koefisien jalur interaksi antara opini audit dengan spesialisasi auditor sebesar 0,423, hal ini memberikan penjelasan bahwa apabila interaksi antara opini audit dan spesialisasi auditor mendapat kenaikan satu satuan, dapat memberikan peningkatan audit report lag sebesar 0,423 satuan. Nilai koefisien jalur interaksi antara opini audit dengan spesialisasi auditor sebesar 0,423, hal ini memberikan penjelasan bahwa apabila interaksi antara opini audit dan spesialisasi auditor mendapat kenaikan satu satuan, dapat memberikan peningkatan audit report lag sebesar 0,423 satuan. Nilai koefisien jalur interaksi antara pergantian auditor dengan spesialisasi auditor sebesar 0,181, hal ini memberikan penjelasan bahwa apabila interaksi antara pergantian auditor dan spesialisasi auditor mendapat kenaikan satu satuan, dapat memberikan audit report lag sebesar 0,181.

Hipotesis pertama $\left(\mathrm{H}_{1}\right)$ menyatakan kualitas KAP berpengaruh negatif terhadap audit report lag. Hasil analisis diagram jalur memperlihatkan bahwa koefisien variabel kualitas KAP sebesar -0,251 dengan nilai P-Value 0,044 lebih kecil dari 0,05, hal ini menunjukan bahwa variabel kualitas KAP berpengaruh negatif terhadap audit report lag, dapat dikatakan $\mathrm{H}_{1}$ diterima. Kualitas KAP baik mempunyai auditor yang kompeten dan profesional dalam pengerjaan audit jika bergabung dengan KAP big four, sehingga mempersingkat audit report lag.

Hipotesis kedua $\left(\mathrm{H}_{2}\right)$ menyatakan opini audit berpengaruh positif tidak signifikan terhadap audit report lag. Hasil analisis diagram jalur memperlihatkan bahwa koefisien variabel opini audit sebesar 0,062 dengan nilai $P$-Value 0,347 lebih besar dari 0,05, hal ini menunjukan bahwa variabel kualitas KAP berpengaruh tidak signifikan terhadap audit report lag, sehingga $\mathrm{H}_{2}$ ditolak. Pemberian opini audit terlalu cepat dan lambat tidak mempercepat pelaksanaan audit report lag.

Hipotesis ketiga $\left(\mathrm{H}_{3}\right)$ menyatakan pergantian auditor berpengaruh positif tidak signifikan terhadap audit report lag. Hasil analisis diagram jalur memperlihatkan bahwa koefisien variabel opini audit sebesar 0,005 dengan nilai $P$-Value 0,488 lebih besar dari 0,05, hal ini menunjukan bahwa variabel kualitas KAP berpengaruh tidak signifikan terhadap audit report lag, dengan kata lain $\mathrm{H}_{3}$ ditolak. Pergantian auditor dilakukan perusahaan biasanya tiga tahun berturut- 
turut setelah laporan audited dilakukan oleh auditor serupa, sehingga pergantian auditor bisa saja menghambat pelaksanaan audit report lag.

Hipotesis keempat $\left(\mathrm{H}_{4}\right)$ menyatakan spesialisasi auditor memperkuat pengaruh negatif kualitas KAP terhadap audit report lag. Hasil analisis diagram jalur memperlihatkan nilai hubungan moderasi spesialisasi auditor dan kualitas KAP terhadap audit report lag sebesar 0,179 dengan nilai P-value 0,118, hal ini menunjukan bahwa variabel moderasi spesialisasi auditor tidak mampu memperkuat pengaruh negatif kualitas KAP terhadap audit report lag, sehingga H4 ditolak. Dengan kata lain, kemampuan auditor berada di KAP yang besar tidak dapat membantu mempercepat audit report lag.

Hipotesis kelima $\left(\mathrm{H}_{5}\right)$ menyatakan spesialisasi auditor memperkuat pengaruh positif opini audit terhadap audit report lag. Hasil analisis diagram jalur memperlihatkan nilai hubungan moderasi spesialisasi auditor dan kualitas KAP terhadap audit report lag sebesar 0,423 dengan nilai P-value 0,001, hal ini menunjukan bahwa variabel moderasi spesialisasi auditor mampu memperkuat pengaruh positif opini audit terhadap audit report lag, sehingga $\mathrm{H}_{5}$ diterima. Dengan kata lain, kemampuan auditor dapat mempersingkat opini audit pada audit report lag.

Hipotesis keenam $\left(\mathrm{H}_{6}\right)$ menyatakan spesialisasi auditor memperkuat pengaruh positif pergantian auditor terhadap audit report lag. Hasil analisis diagram jalur memperlihatkan nilai hubungan moderasi spesialisasi auditor dan pergantian auditor terhadap audit report lag sebesar 0.181 dengan nilai $P$-value 0,115, hal ini menunjukan bahwa variabel moderasi spesialisasi auditor tidak mampu memperkuat pengaruh positif pergantian auditor terhadap audit report lag, sehingga $\mathrm{H}_{6}$ ditolak. Dengan kata lain, kemampuan auditor yang baru tidak dapat mempercepat audit report lag.

\section{SIMPULAN}

Simpulan dari penelitian ini adalah sebagai berikut: Kualitas KAP berpengaruh negatif secara signifikan terhadap audit report lag. Opini audit berpengaruh positif tidak signifikan terhadap audit report lag. Pergantian auditor berpengaruh positif tidak signifikan terhadap audit report lag. Spesialisasi auditor mampu memperkuat pengaruh positif opini audit terhadap audit report lag. Spesialisasi auditor mampu memperkuat pengaruh positif opini audit tidak signifikan terhadap audit report lag. Spesialisasi auditor tidak mampu memperkuat pengaruh positif tidak signifikan pergantian auditor terhadap audit report lag.

Saran untuk perusahaan adalah dalam menggunakan jasa audit, harus memilih Kantor Akuntan Publik (KAP) yang mempunyai kualitas auditor yang handal, sehingga laporan keuangan yang diaudit terlaksana dengan tepat waktu. Untuk penelitian selanjutnya hendaknya memperluas variabel yaitu jumlah klien dan kompetensi dengan tetap variabel bebasnya, sehingga penelitian selanjutnya memberikan spesialisasi auditor dengan keahlian masing-masing auditor.

\section{REFERENSI}

Adiwibowo, A. S., \& Makhabati, D. N. E. (2019). Pengaruh Spesialisasi Industri Kap, Reputasi Auditor, Dan Audit Tenure Terhadap Audit Report Lag. Diponegoro Journal Of Accounting, 8, 2337-3806. 
Agoes, S. (2017). Auditing; Petunjuk Praktis Pemeriksaan Akuntan Oleh Akuntan Publik (S. Emapat (Ed.); 5th Ed.).

Arens, Et al. (2017). Auditing And Integrated Approach (S. Empat (Ed.); 11th Ed.).

Ariani, Kurnia Rinalag, E. U. D., \& Bawono, A. D. B. (2018). Pengaruh Ukuran Dan Umur Perusahaan Terhadap Audit Report Lag Dengan Profitabilitas Dan Solvabilitas Sebagai Variabel Moderating. Riset Akuntansi Dan Keuangan Indonesia, 3.

Aristika, M. N., Trisnawati, R., \& Handayani, C. D. (2016). Pengaruh Opini Audit, Ukuran Perusahaan, Umur Perusahaan, Dan Laba Rugi Terhadap Audit Report Lag. Syariah Paper Accounting FEB UMS.

Azzuhri, H., Kamaliah, \& M.Rasuli. (2019). Pengaruh Audit Tenure, Kompleksitas Operasi Perusahaan, Kualitas Dan Opini Audit Terhadap Audit Report Lag Dengan Spesialisasi Industri Auditor Eksternal Sebagai Variabel Moderasi. Pekbis Jurnal.

Darsono, U. (2015). Faktor-Faktor Yang Mempengaruhi Ketepatan Waktu Pelaporan Keuangan Tahunan Perusahaan. UNDIP E-Jurnal Akuntansi, 4.3, 110.

Dewangga, A., \& Laksito, H. (2015). Faktor-Faktor Yang Berpengaruh Terhadap Audit Report Lag. Diponegoro Journal Of Accounting, 4, 2337-3806.

Dewi, G., \& Suputra, I. D. (2017). Pengaruh Kompleksitas Operasi, Kontijensi, Pergantian Auditor Pada Audit Report LAG Dengan Spesilisasi Auditor Sebagai Pemoderasi. E-Jurnal Akuntansi, 21.2, 912-941.

Diastiningsih, N., \& Tenaya, G. (2017). Spesilisasi Auditor Sebagai Pemoderasi Pengaruh Audit Tenure Dan Ukuran KAP Pada Audit Report Lag. E-Jurnal Akuntansi, 18.2, 1230-1258.

Gaol, R. L., \& Sitohang, M. (2020). Pengaruh Pergantian Auditor, Ukuran KAP, Sovabilitas, Dan Umur Perushaan Terhadap Audit Report Lag. JRAK.

Ghozali, I., \& Latan, H. (2015). Konsep, Teknik, Aplikasi Menggunakan Smart PLS 3.0 Untuk Penelitian Empiris. BP Undip. Semarang.

Ginting, I. A. (2019). Pengaruh Profitabilitas, Solvabilitas, Pergantian Uditor,Ukuran Kap Dan Kompleksitas Operasi Perusahaan Terhadap Audit Report Lag Pada Perusahaan Manufaktur Yang Terdaftar Di Bursa Efek Indonesia Periode 2015 - 2017. Universitas Sumatera Utara.

Hapsari, A. N., Putri, N. K., \& Arofah, T. (2016). The Influence Of Profitability, Solvency, And Auditor's Opinion To Audit Report Lag At Coal Mining Companies. Binus Business Review. Https:/ /Doi.Org/10.21512/Bbr.V7i2.1685

Herawati, H. (2019). Pentingnya Laporan Keuangan Untuk Menilai Kinerja Keuangan Perusahaan. Jaz:Jurnal Akuntansi Unihaz.

Ikatan Akuntan Indonesia, \& Hadad, M. D. (2016). Peraturan Otoris Jasa Keuangan Nomor 29 /POJK.04/2016 Tentang Laporan Tahunan Emiten Atau Perusahaan Publik. Otoritas Jasa Keuangan Republik Indonesia.

Lisa, O. (2012). Asimetri Informasi Dan Manajemen Laba: Suatu Tinjauan Dalam Hubungan Keagenan. WIGA, 2.1.

Mayhew, B., \& Wilkins, M. (2003). Audit Firm Industry Specialization As A Differentiation Strategy: Evidence From Fees Charged To Firms Going Public. A Journal Of Practice \& Theory, 22.2, 33-52.

Mazkiyani, N., \& Handoyo, S. (2017). Audit Report Lag Of Listed Companies In 
Indonesia Stock Exchange. Jurnal Aplikasi Bisnis. Https://Doi.Org/10.20885/Jabis.Vol17.Iss1.Art5

Mulyadi. (2014). Sistem Akuntansi Edisi 4. In Salemba Empat.

Nur Affifah, A., \& Susilowati, E. (2021). Pengaruh Audit Tenure Dan Ukuran Kap Terhadap Audit Report Lag (Arl) Dengan Kualitas Audit Sebagai Variabel Intervening. Akuntansi Dan Manajemen. Https:// Doi.Org/10.30630/Jam.V16i1.135

Nurintiati, A., \& Purwanto, A. (2017). Pengaruh Tenure Kap, Ukuran Kap, Spesialisasi Auditor Dan Audit Fee Terhadap Kualitas Audit Dengan Moderasi Komite Audit. Diponegoro Journal Of Accounting.

Praptika, P., \& Rasmini, N. (2016). Pengaruh Audit Tenure, Pergantian Auditor Dan Financial Distress Pada Audit Delay Pada Perusahaan Consumer Goods. E-Jurnal Akuntansi.

Ratnaningsih, N., \& Dwirandra, A. (2016). Spesialisasi Auditor Sebagai Variabel Pemoderasi Pengaruh Audit Tenure Dan Pergantian Auditor Pada Audit Delay. E-Jurnal Akuntansi.

Sumartini, N. K. A., \& Widhiyani, N. L. S. (2014). Pengaruh Opini Audit, Solvabilitas, Ukuran Kap Dan Laba Rugi Pada Audit Report Lag. E-Jurnal Akuntansi Universitas Udayana.

Sylviana, D. (2019). Pengaruh Solvabilitas , Pergantian Auditor Dan Opini Auditor Terhadap Audit Delay. Seminar Nasional Teknologi Komputer \& Sains (SAINTEKS).

Tambunan, P. U. (2014). Pengaruh Opini Audit, Pergantian Auditor Dan Ukuran Kantor Akuntan Publik Terhadap Audit Report Lag (Studi Empiris Pada Perusahaan Manufaktur Yang Terdaftar Di Bursa Efek Indonesia ). Jurnal Akuntansi Universitas Negeri Padang.

Telaumbanua, D. J. W., Dwisyafitri, I. J., Sherlia, B., Hutabalian, H., Rahmad, \& Ginting, W. A. (2020). Pengaruh Pergantian Auditor, Ukuran Kap, Dan Laba Rugi Terhadap Audit Report Lag. Jurnal Ilmiah Mea(Manajemen, Ekonomi, Dan Akuntansi).

Togasima, C. N., \& Christiawan, Y. J. (2014). Analisis Faktor-Faktor Yang Mempengaruhi Audit Report Lag Pada Perusahaan Yang Terdaftar Di Bursa Efek Indonesia Pada Tahun 2012. Business Accounting Review, 2, 151-159.

Utami, W. B., Pardanawati, L., \& Septianingsih, I. (2018). The Effect Of Audit Opinion, Public Accounting Firm's Size, Company Size, And Company Profitability To Delay Audits In Registered Manufacturing Companies In Indonesia Stock Exchange In 2015-2017. International Journal Of Economics, Business And Accounting Research (IJEBAR). Https:/ / Doi.Org/10.29040/Ijebar.V2i3.345

Yudhi, Y. P., Ahmar, N., \& Syam, M. A. (2020). Determinan Audit Report Lag Dan Peran Auditor Spesialisasi Industri Sebagai Pemoderasi Pada Perusahaan Badan Usaha Milik Negara. Jurnal Riset Akuntansi \& Perpajakan (JRAP). Https:/ / Doi.Org/10.35838/Jrap.V7i01.1496 